\title{
Appendiceal Carcinoma cMO TNM Finding v7
}

National Cancer Institute

\section{Source}

National Cancer Institute. Appendiceal Carcinoma cMO TNM Finding v7. NCI Thesaurus. Code $C 89915$.

Appendiceal carcinoma without evidence of distant metastasis. (from AJCC 7th Ed.) 